\title{
The Elements of Water Balance in the Changing Climate in Poland
}

\author{
Małgorzata Szwed \\ Institute for Agricultural and Forest Environment of Polish Academy of Sciences, Bukowska 19, 60-809 Poznań, Poland \\ Correspondence should be addressed to Małgorzata Szwed; mszwed@man.poznan.pl
}

Received 7 November 2014; Revised 9 February 2015; Accepted 10 February 2015

Academic Editor: Yongqiang Zhang

Copyright (C) 2015 Małgorzata Szwed. This is an open access article distributed under the Creative Commons Attribution License, which permits unrestricted use, distribution, and reproduction in any medium, provided the original work is properly cited.

\begin{abstract}
Strong global warming has been observed in the last three decades. Central Europe, including Poland, is not an exception. Moreover, climate projections for Poland foresee further warming as well as changes in the spatial and seasonal distribution and quantity of precipitation. However, climate models do not agree on the sign of change of precipitation. In Poland precipitation is projected to decrease in summer (this finding is not robust, being model-dependent) and to increase in winter. Therefore, there is still considerable uncertainty regarding likely climate change impacts on water resources in Poland. However, there is no doubt that changes in the thermal characteristics as well as in precipitation will influence changes in the water balance of the country. In this study, the components of climatic water balance, that is, precipitation, evaporation, and runoff, are calculated for the average conditions in the control period of 1961-1990 and in the future (2071-2100) in Poland. The changes of the water balance components for the present and for the future are compared and analysed. Due to insufficient consistency between climate models a possible range of changes should be presented; hence the multimodel projections from ENSEMBLES Project of the European Union are used in this study.
\end{abstract}

\section{Background}

There is persuading evidence (cf. [1]) that significant global warming has been observed over more than a century and a particularly strong warming-over the last three decades. Central Europe, including Poland, is not an exception. Moreover, climate projections for Poland foresee further warming in all seasons, as well as changes in the distribution and quantity of precipitation.

Observations and climate model simulations indicate an acceleration of the water cycle, with possible consequences to extremes $[2,3]$. A warmer climate is likely to increase risks of both floods and droughts in many areas $[1,4]$.

In the present climate, many regions of Poland (and predominantly the Wielkopolska region) suffer frequent shortages of water, especially in the growing season. Water problems in the Wielkopolska region are particularly critical due to the agricultural character of this region. On the other hand, increase in intense precipitation in a warming Europe (also in Poland) is observed and projected [5] and may increase flood hazard. In the last two decades Poland experienced many extreme events connected with heavy precipitations, for example, floods in 1997 and 2010.

Climate changes noticeable today are projected to intensify in the future. Therefore, water shortages/surpluses may be even more common and more severe in the future. Changes in the thermal characteristics as well as in precipitation are projected to influence changes in the climatic water balance in the country. What will they be like? In what way will they influence the water conditions in Poland? Will they be spatially differentiated or perhaps have similar character in the entire country? Unfortunately, climate projections for the future foresee detrimental changes in water availability caused mainly by higher temperature accompanied by simultaneous changes in the distribution and quantity of precipitations. For the northern part of Europe, the average precipitation is projected to increase while for the southern part considerable decreases are projected in brief-dry areas are likely to be much drier and wetter-to become wetter. Effects of future climate change on precipitation and water 
resources in Poland are particularly uncertain due to location of Poland in the zone between northern Europe getting wetter and the south of Europe getting drier.

In the present paper, changes in the water balance in Poland are evaluated, based on multimodel ensemble climate projections, obtained within the ENSEMBLES Project of the 6th Framework Programme of the European Union.

\section{Data}

In this study, based on results from different climate models, time series of ten-day values of the climatic water balance components, that is, precipitation, evaporation, and runoff, are examined for the average conditions in two time horizons, that is, 1961-1990 (control period) and 2061-2090, for selected stations over Poland.

For climate simulation, the model is expected to approximately reproduce the observed distribution of mean temperature and of mean daily and seasonal cycles of temperature since these are forced deterministic components. The remaining variability is an internally generated nonlinear natural random component. Its modelled and observed values are not expected to be correlated either. Thus, as characteristic for intercomparison results, different climate variables are simulated with various levels of success by different models and no single model is the "best" for all variables or for all areas. Different studies on climate change suggest that, due to insufficient consistency between climate models, the broadest possible range of changes should be presented, which represent uncertainty. Therefore, the multimodel projections from the ENSEMBLES EU Project are used in this study.

The main calculations are based on the simulation results of daily temperature, precipitation, relative humidity, and wind speed from five ENSEMBLES regional climate models for 16 grid-cells around Poland. In selected gridcells, 16 Polish towns and cities are situated entirely or partly, that is, Bialystok, Chojnice, Gorzow Wielkopolski, Hel, Katowice, Kielce, Lodz, Olsztyn, Poznan, Rzeszow, Suwalki, Swinoujscie, Warszawa, Wlodawa, Wroclaw, and Zielona Gora (Figure 1). In this research chosen grid-cells are called conventionally after the name of the city which is located there.

The regional models from the ENSEMBLES Project used in this study are C4IRCA 3 from Rossby Centre (Norrköping, Sweden); CLM from ETH (Zurich, Switzerland); KNMIRACMO2 from the Royal National Meteorological Institute (de Bilt, the Netherlands); METO-HC from the Met Office's Hadley Centre (Exeter, UK); and MPI-M-REMO from the Max Planck Institute (Hamburg, Germany). Chosen regional climatic models were generated based on two different global circulation models (GCMs). Regional models C4IRCA3, ETHZ-CLM, and METO-HC are based on the global model METO-HC Standard, while models MPI-MREMO and KNMI-RACMO2 are calibrated based on the global circulation model ECHAM of fifth generation.

All of the used ENSEMBLES regional climate models cover Europe with a spatial resolution of about 25 by $25 \mathrm{~km}$ and draw just one possible future, corresponding to a specific SRES emission scenario, A1B [6].

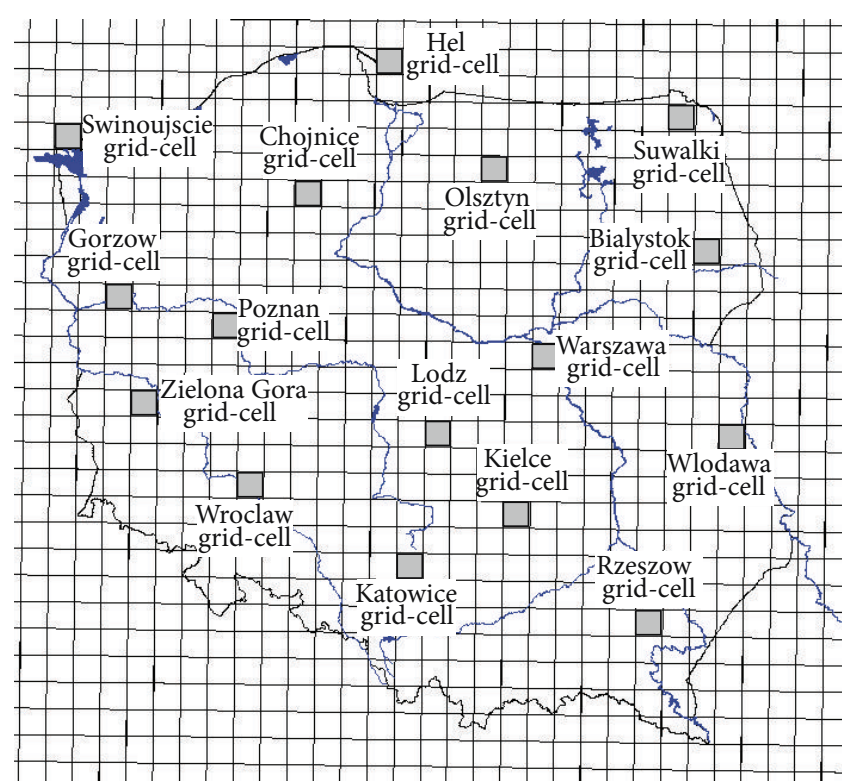

FIGURE 1: The studied grid-cells (grid-cell containing the towns/cities over Poland).

In order to verify model simulations and to assess the usefulness of the ENSEMBLES RCM models for this research, the control period data (1961-1990) from the models were compared to observation data for selected stations in Poland for the same period.

\section{Verification of the Models}

The models were validated for the territory of Poland based on monthly observational data of temperature and precipitation for the reference period of 1961-1990 and values simulated by five ENSEMBLES models for the same period. The validation was significantly simplified as observational data represented individual points in space derived from the observation station and the model data were averaged for the surface (usually a square $25 \mathrm{~km} \times 25 \mathrm{~km}$ ). So in fact, values of the meteorological variables for the points were compared with the values of the same variables for the grid-cell where these points (stations in towns) are located. Validation was carried out for 16 stations in case of the temperature and for 19 stations in case of precipitation and for 16 and 19 grid-cells, respectively. Unfortunately, it was not possible to carry out detailed areal validation due to lack of data.

There are many ways to measure the skill of model simulations. In a study by Szwed et al. [7] the models were validated based on such characteristics as sum of absolute differences between real and predicted values, standard deviations, and variances and correlation between real and predicted values of the monthly data. These second-order measures were analysed in the annual and seasonal context, for the warm and cold thermal seasons.

For every point in space (observational station) the models were ranked from 1 (best) to 5 (worst) according to following rules: (i) correlation level (the higher positive the better); (ii) sum of squared differences (the lower the better); 
TABLE 1: Comparison of modelled and observed temperature for the city of Poznan referring to second-order statistics: sums of squared differences, ratios of variances, and correlation coefficients (corresponding rank in brackets) and the final ranks for the models based on the temperature.

\begin{tabular}{|c|c|c|c|c|}
\hline Model & $\begin{array}{c}\text { Sum of squared } \\
\text { differences } \\
\text { (model - real) in }{ }^{\circ} \mathrm{C}\end{array}$ & $\begin{array}{c}\text { Ratio of variance of the model to } \\
\text { observational variance }\end{array}$ & Correlation & Final rank \\
\hline C4IRCA & $18.61(4)$ & $1.047(1)$ & $0.9967(3)$ & 3 \\
\hline ETHZ & $21.46(5)$ & $1.282(5)$ & $0.9947(5)$ & 5 \\
\hline KNMI & $10.23(2)$ & $0.823(3)$ & $0.9974(1)$ & 2 \\
\hline METO-HC & $16.35(3)$ & $1.218(4)$ & $0.9955(4)$ & 4 \\
\hline MPI-M-REMO & $6.48(1)$ & $0.867(2)$ & $0.9973(2)$ & 1 \\
\hline
\end{tabular}

TABLE 2: Verification of models for temperature. The final ranks of models for all the stations and the mean ranks for Poland.

\begin{tabular}{|c|c|c|c|c|c|c|c|c|c|c|c|c|c|c|c|c|c|c|}
\hline$\frac{\vec{d}}{\stackrel{0}{\Sigma}}$ & 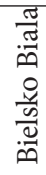 & $\begin{array}{l}\stackrel{U}{\Xi} \\
\frac{\mathcal{O}}{0} \\
\end{array}$ & $\underset{\mathbb{I}}{\mathbb{U}}$ & 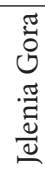 & 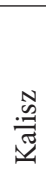 & 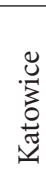 & 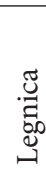 & 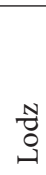 & $\begin{array}{l}\text { ज्ञ్ } \\
\text { О } \\
\text { م }\end{array}$ & 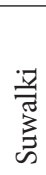 & 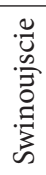 & $\begin{array}{l}\Xi \\
\text { J } \\
\text { N } \\
\text { N }\end{array}$ & $\underbrace{\Xi}_{0}$ & 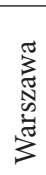 & $\begin{array}{l}\frac{\pi}{3} \\
\frac{\pi}{0} \\
\frac{0}{3}\end{array}$ & $\begin{array}{l}\frac{3}{0} \\
\frac{3}{0} \\
0 \\
3\end{array}$ & 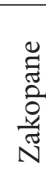 & 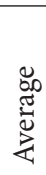 \\
\hline C4IRCA & 3 & 3 & 1 & 3 & 3 & 3 & 3 & 3 & 3 & 3 & 1 & 1 & 3 & 3 & 3 & 3 & 3 & 3 \\
\hline ETHZ & 5 & 5 & 3 & 5 & 5 & 5 & 5 & 5 & 5 & 5 & 5 & 5 & 5 & 5 & 5 & 5 & 5 & 5 \\
\hline KNMI & 2 & 2 & 4 & 1 & 2 & 2 & 2 & 2 & 2 & 1 & 3 & 2 & 2 & 2 & 2 & 2 & 2 & 2 \\
\hline METO-HC & 4 & 4 & 2 & 4 & 4 & 4 & 4 & 4 & 4 & 4 & 2 & 4 & 4 & 4 & 4 & 4 & 4 & 4 \\
\hline MPI-M-REMO & 1 & 1 & 5 & 2 & 1 & 1 & 1 & 1 & 1 & 2 & 4 & 3 & 1 & 1 & 1 & 1 & 1 & 1 \\
\hline
\end{tabular}

(iii) variances for the model (the better fit to observational variances the better). The ultimate rank for each model was established by multiplication of all previously calculated ranks. This procedure was applied separately to the values of temperature and precipitation. Finally, for every model its "average value for Poland" was calculated as an average range from all the station data.

3.1. Validation for Temperature. The models are reasonably successful in reproducing/simulating the observed distribution of mean temperature and of seasonal cycles of temperature. Table 1 presents the comparison of two data sets (modelled and observed) referring to second-order statistics, such as square differences, variances, and the associated correlation for the city of Poznan.

The average value of correlation for Poland between the observed and the modelled temperature (mean value for all the station data) is 0.99 or more for every model. There is no one "best" model for the whole area of Poland. The degree of consistency between modelled and observed values varies between models and is location-specific. Yet, in all the studied models, mapping of the average temperature is by far the worst for the coastal areas, while being the best for some central parts, depending on the model.

It seems, based on range values, that the MPI-M-REMO and KNMI models simulate the temperature in the reference period 1961-1990 a little better than the other models (Table 2). Applications using modelled temperature data for Poland should be based on an ensemble of models, so that the range of uncertainty, resulting from model disagreement, is adequately illustrated.
3.2. Validation for Precipitation. As for precipitation, in most cases the agreement between climate models and real data for the control period is not satisfactory. There are very high monthly and seasonal differences of modelled precipitation values from the climatological mean. In some cases unrealistic distributions of annual precipitation seem to negate the usefulness of certain models. Table 3 presents the comparison of two data sets referring to second-order statistics, such as square differences, variances, and the associated correlation for the city of Poznan, for precipitation.

"Average correlations for Poland" (mean value for all the station data) between observed and predicted values for every model are rather low and vary from 0.014 to 0.864 . There are even negative correlations for some stations for 3 of models (C4IRCA, for 9 stations, ETHZ, for 5 stations, and METO$\mathrm{HC}$, for 2 stations). The degree of consistency between modelled and observed values varies between models and is location-specific. It seems, based on range values, that, for Poland, the MPI-M-REMO model (from the ENSEMBLES set) simulates the precipitation in the reference period 19611990 better than other models (Table 4).

To recapitulate, Figure 2 (according to the concept of diagram from [8]) gives the standard deviation and correlation with observations of the total spatial and temporal variability of temperature and precipitation in the validated models (mean value for 16 stations for temperature and 19 stations for precipitation, resp.). The standard deviation is normalized to its observed value and the correlation ranges from zero along an upward vertical line ( $y$-axis) to unity and along a line pointing to the right ( $x$-axis). Consequently, the observed behaviour of the climate is represented by a point on the horizontal axis which is a unit distance from the origin. 
TABLE 3: Comparison of modelled and observed precipitation for the city of Poznan referring to second-order statistics: sums of squared differences, ratios of variances, and correlation coefficients (corresponding rank in brackets) and the final ranks for the models based on the precipitation.

\begin{tabular}{|c|c|c|c|c|}
\hline Model & $\begin{array}{l}\text { Sum of squared differences } \\
\text { (model - real) in mm }\end{array}$ & $\begin{array}{l}\text { Ratio of variance of the } \\
\text { model to observational } \\
\text { variance }\end{array}$ & Correlation & Final rank \\
\hline C4IRCA & $5583.10(5)$ & $0.284(4)$ & $0.123(5)$ & 5 \\
\hline ETHZ & $4971.38(3)$ & $0.255(5)$ & $0.362(4)$ & 4 \\
\hline KNMI & $4172.73(2)$ & $0.503(3)$ & $0.709(2)$ & 2 \\
\hline METO-HC & $5543.56(4)$ & $1.096(2)$ & $0.563(3)$ & 3 \\
\hline MPI-M-REMO & $3619.26(1)$ & $1.028(1)$ & $0.846(1)$ & 1 \\
\hline
\end{tabular}

TABLE 4: Verification of models for precipitation. The final ranks of models for all the stations and the mean ranks for Poland.

\begin{tabular}{|c|c|c|c|c|c|c|c|c|c|c|c|c|c|c|c|c|c|c|c|c|c|}
\hline $\begin{array}{l}\overrightarrow{0} \\
\stackrel{0}{0} \\
\Sigma\end{array}$ & 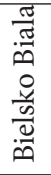 & $\frac{\stackrel{\Xi}{\Xi}}{\stackrel{\Xi}{0}}$ & $\underset{\mathbb{I}}{\vec{I}}$ & 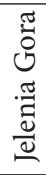 & 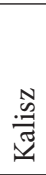 & 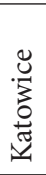 & 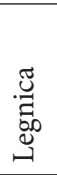 & 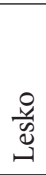 & 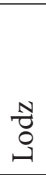 & $\begin{array}{l}\text { जี } \\
\text { בิ } \\
\text { م }\end{array}$ & 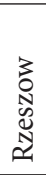 & 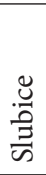 & 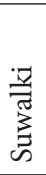 & 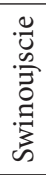 & $\begin{array}{l}\text { U. } \\
\text { N } \\
\text { N }\end{array}$ & $\underset{ٍ}{\Xi}$ & 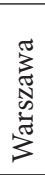 & $\frac{\sqrt[\pi]{3}}{\frac{\pi}{0}}$ & $\begin{array}{l}\frac{3}{3} \\
\stackrel{3}{0} \\
3 \\
3\end{array}$ & 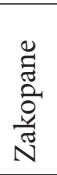 & \begin{tabular}{l}
0 \\
\multirow{\pi}{*}{} \\
$\sum^{2}$ \\
\end{tabular} \\
\hline C4IRCA & 5 & 5 & 3 & 5 & 5 & 5 & 5 & 5 & 5 & 5 & 5 & 5 & 5 & 1 & 5 & 4 & 5 & 5 & 4 & 4 & 5 \\
\hline ETHZ & 4 & 3 & 4 & 2 & 4 & 4 & 4 & 4 & 4 & 4 & 4 & 4 & 4 & 5 & 3 & 5 & 4 & 4 & 4 & 2 & 4 \\
\hline KNMI & 3 & 3 & 2 & 4 & 2 & 3 & 3 & 3 & 3 & 2 & 3 & 2 & 3 & 2 & 2 & 3 & 2 & 3 & 3 & 1 & 3 \\
\hline METO-HC & 2 & 2 & 5 & 3 & 2 & 2 & 1 & 2 & 2 & 3 & 2 & 3 & 2 & 3 & 1 & 2 & 1 & 2 & 2 & 3 & 2 \\
\hline MPI-M-REMO & 1 & 1 & 1 & 1 & 1 & 1 & 2 & 1 & 1 & 1 & 1 & 1 & 1 & 4 & 4 & 1 & 2 & 1 & 1 & 5 & 1 \\
\hline
\end{tabular}

In this coordinate system, the linear distance between each model's point and the "observed" point is proportional to the r.m.s. model error [8]. Based on this figure, it can be concluded that the temperature is particularly well simulated, with nearly all models closely matching the observed magnitude of variance and exhibiting a correlation more than 0.99 with the observations. Precipitation is simulated rather poorly, but for the MPI-M-REMO model the simulated variance is still within $20 \%$ of observed one and the correlation with observations is noticeably positive $(0.78)$.

Thus, the outcome of the verification of models for the territory of Poland indicates that MPI-M-REMO model provides the best fit for both temperature and precipitation conditions. That is why the results of this model are presented in this paper in more detail. Nevertheless, as it was mentioned before, due to insufficient consistency between climate models, the full possible ranges of changes are presented.

\section{Methods}

The climatic water balance equation is the starting-point for all the calculations in this study. It is usually written as $P=H+E+\Delta R$, where $P$ is the precipitation, $H$ is the climatic runoff, $E$ is the evaporation, and $\Delta R$ is the change of retention (storage). If the assumption of no changes in retention is made (for appropriately long time horizon), the equation of water balance becomes $P=H+E$. So the climatic runoff is calculated as the difference between precipitation and evaporation. Water balance components are expressed in millimetres of water layer.
From the variables of water balance which should be examined in this research only precipitation, input of water, is "directly" available from models. However "output of water," that is, climatic runoff and evaporation, is an essence of the problem. It is very important to know whether precipitation "is enough" and what part of water remains "at disposal." Output elements of the water balance have to be estimated for further analyses.

In this research, the values of evaporation for the different land-use units for the growing season (March-October) are estimated based on the heat balance method developed in the Department of Agrometeorology of the Poznan University of Life Sciences [9]. This method was developed for the purpose of estimating heat balance components based on standard meteorological data, plant development stage, and land-use conditions. Estimates of latent heat flux components allowed obtaining values of areal evaporation and surface runoff.

The energy balance equation is $\mathrm{Rn}+\mathrm{LE}+A+G=0$, where $\mathrm{Rn}$ is the net radiation, LE is the latent heat flux, $A$ is the sensible heat flux, and $G$ is the soil heat flux. In the remaining part of the year (November-February), the values of evaporation were calculated based on the Ivanov equation; that is, $\mathrm{LE}=0.0018 \cdot(T+25)^{2} \cdot(100-\mathrm{Rh})$, where $T$ is the air temperature and $\mathrm{Rh}$ is the relative humidity [10]. The latent heat flux is used for calculating the actual evaporation because a simple relationship exists between evaporation expressed in $\mathrm{mm}(E)$ and latent heat expressed in $\mathrm{MJ} \cdot \mathrm{m}^{-2}$ (LE); that is, $E=\mathrm{LE} / 2.83$.

The method allows estimating heat balance components based on standard meteorological data, plant development stage, and land-use conditions. The heat balance components are expressed in mega joules per square meter and given 


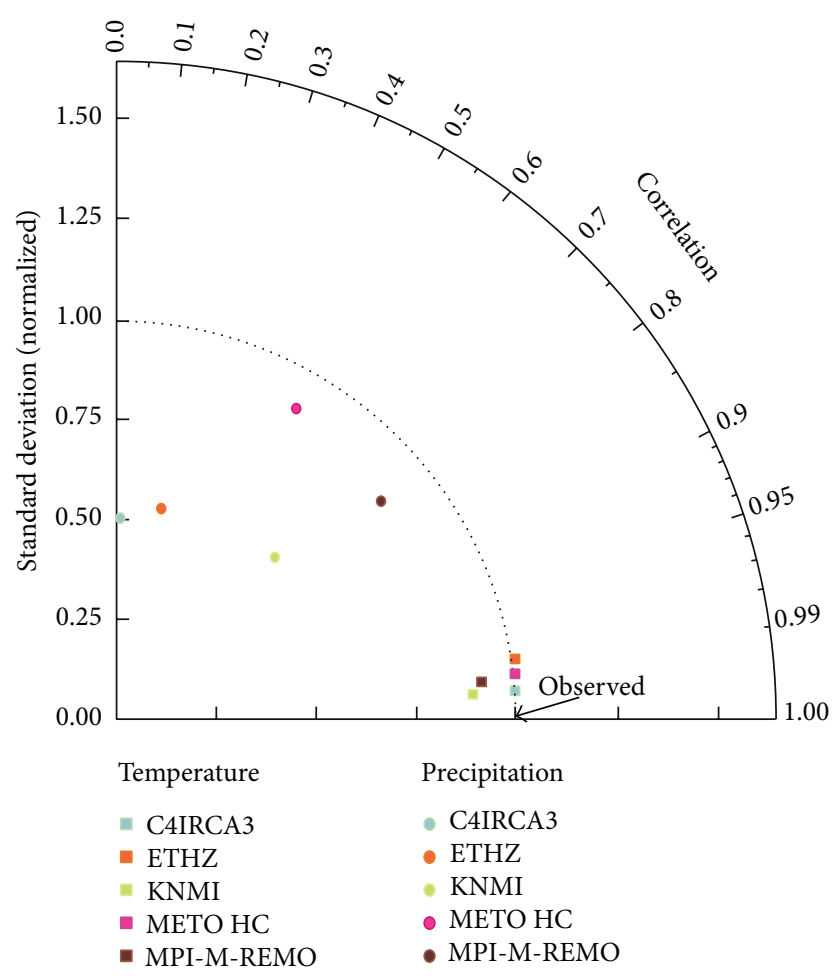

FIGURE 2: Taylor diagram-the standard deviation and correlation of the validated models with observations for temperature and precipitation (mean value for all the stations around Poland).

period $\left[\mathrm{MJ} \cdot \mathrm{m}^{-2} \cdot\right.$ period $\left.^{-1}\right]$ or in Watts per square meter $\left[\mathrm{W} \cdot \mathrm{m}^{-1}\right]$. All fluxes towards the active surface are taken as positive while the outgoing fluxes are assumed negative.

In the applied method, time series of ten-day values of precipitation, air temperature, relative humidity, and wind speed stemming from regional climate models are used. Tenday values of sunshine duration are calculated based on the sunshine duration model for Poland according to Górski and Górska [11], whereas values of plant development stages are assumed according to Leśny [12].

The heat and water balance structure depends not only on meteorological conditions but also on many environmental factors as well as plant characteristics. In this study, for all analysed grid-cells the land-use structure is assessed based on the Corine Land Cover 2000 as well as on additional data from the Statistical Yearbooks for Poland (e.g., Figures 3 and 4). In this paper eight types of physiographical units are taken into account, namely, coniferous and deciduous forests, arable lands (including cereal and root crops), meadows, wastelands, water bodies, and urban areas. The heat balance components are calculated for all these land-use units.

All estimations are made for two time horizons, that is, the control period 1961-1990 and the future interval of 2061-2090. In spite of the fact that the author has real meteorological observation data (even if pertaining to points rather than providing satisfactory areal coverage) in this study the model-based values of meteorological variables are used also for the present (control period). Hence for estimation of changes of the water balance components in

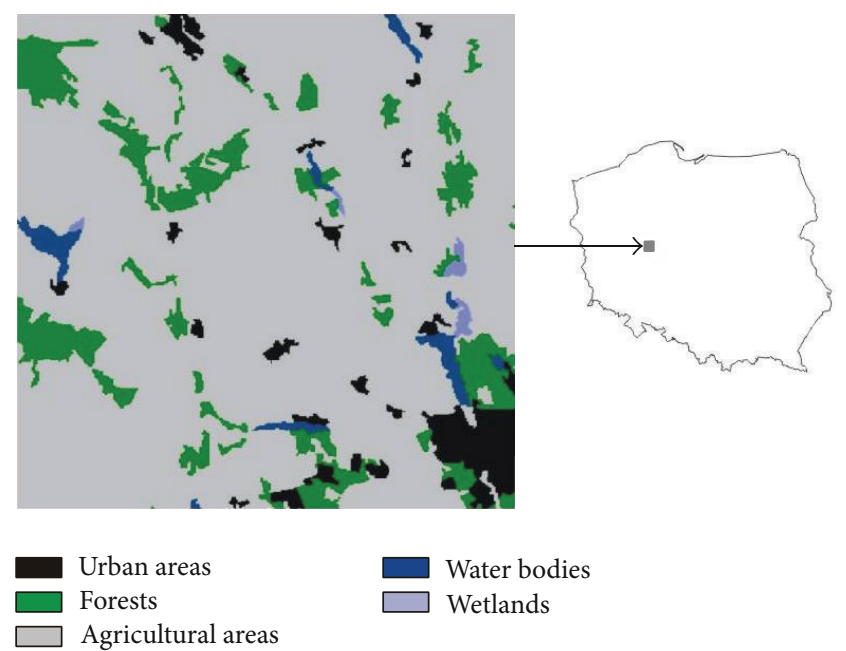

Figure 3: Land-use units near the city of Poznan based on the Corine Land Cover 2000.

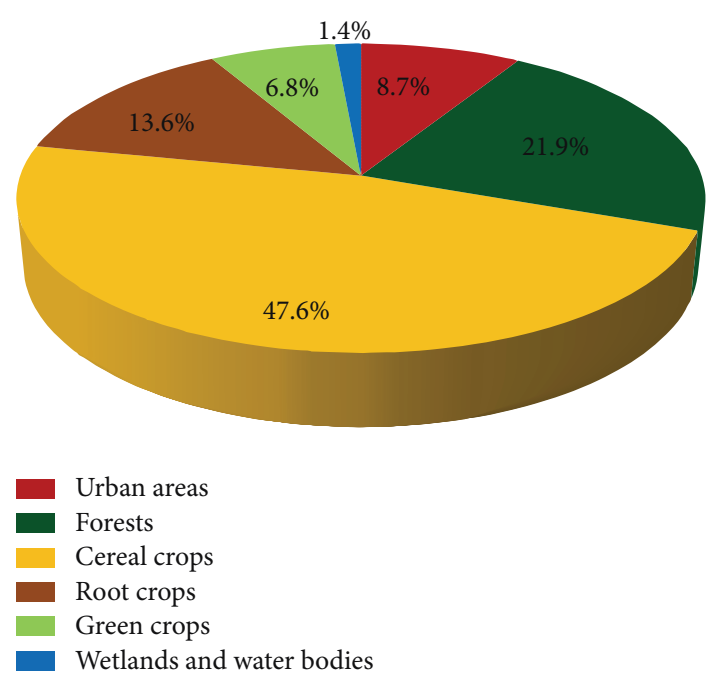

FIgure 4: Land-use units in the Poznan province based on the Statistical Yearbooks for Poland.

the future it seems more sensible to compare model-based simulations for two time horizons of interest than to compare of observations (or reanalyses) from 1961 to 1990 and modelbased projections for 2061-2090.

\section{Results}

Results are presented for two 30-year periods of 19611990 and 2061-2090, that is, the control and the projection period, respectively. The 1961-1990 values are based on model simulations and not on observations. In this study the landuse changes in the future are not taken into consideration.

5.1. Changes in Precipitation. The present value of annual precipitation based on models is slightly overestimated (by about $25-35 \%$ ), but the distribution and values of the monthly precipitation differ significantly between modelled 
TABLE 5: The changes of the annual precipitation [in $\mathrm{mm}$ ] in the future (2061-2090) compared to the control period 1961-1990, based on the MPI-M-REMO model.

\begin{tabular}{lccccccccccccc}
\hline Grid-cell & Jan & Feb & Mar & Apr & May & Jun & Jul & Aug & Sep & Oct & Nov & Dec & Year \\
\hline Bialystok & 8 & 3 & 10 & 12 & 14 & -10 & -3 & 2 & 12 & -6 & 9 & 10 & 60 \\
Chojnice & 11 & 4 & 2 & 3 & 4 & -8 & 6 & -1 & 10 & 5 & 6 & 9 & 51 \\
Gorzow & 8 & -3 & -3 & 6 & -2 & -2 & -5 & -12 & 0 & 6 & 7 & 7 & 8 \\
Hel & 12 & 13 & 9 & 12 & 7 & -2 & 3 & 4 & 6 & 2 & 15 & 24 & 104 \\
Katowice & 8 & 3 & 5 & 16 & 1 & -18 & -14 & -5 & 15 & 0 & 7 & 5 & 22 \\
Kielce & 9 & 3 & 2 & 10 & 4 & -20 & -21 & -4 & 12 & -2 & 12 & 10 & 15 \\
Lodz & 7 & 6 & 0 & 6 & 5 & -13 & -2 & -4 & 16 & -6 & 9 & 9 & 32 \\
Olsztyn & 14 & 5 & 6 & 5 & 9 & 2 & 10 & 13 & 6 & -12 & 7 & 7 \\
Poznan & 6 & 0 & 0 & 5 & -8 & -1 & 6 & -13 & 4 & 1 & 11 & 8 \\
Rzeszow & 10 & 2 & 1 & 12 & -3 & -31 & -22 & -14 & 8 & -6 & 8 & 7 \\
Suwalki & 10 & 6 & 10 & 12 & 9 & -7 & 9 & 11 & 6 & -8 & 9 & 7 \\
Swinoujscie & 5 & 9 & 4 & 6 & 4 & 5 & 12 & -11 & 14 & 7 & 9 & 21 \\
Warszawa & 7 & 3 & 7 & 8 & 6 & -13 & 10 & -5 & 11 & -14 & 15 & 8 \\
Wlodawa & 5 & 0 & 2 & 16 & 5 & -20 & 7 & -9 & 7 & -3 & 6 & 4 \\
Wroclaw & 8 & 1 & 4 & 12 & 10 & -7 & -5 & -12 & 2 & 4 & 7 & 9 \\
Zielona G. & 6 & -1 & -3 & 7 & 1 & 1 & 3 & -8 & 4 & 3 & 9 & 24 \\
\hline
\end{tabular}

and observed data. The winter precipitation is too high, while the summer precipitation is too low. All the models overestimate the values of winter precipitation with surpluses varying from 40 to $140 \%$. On the contrary, precipitation for June and July is often underestimated, even by $30 \%$, while in fact July is the most rainy month. The MPI-M-REMO model overestimates precipitation during all the year.

Mostly the projections for the future foresee increases of annual sum of precipitation. According to MPI-M-REMO model (which correlates best with the current climatic conditions), the annual precipitation is projected to rise in all, but one, considered grid-cells in Poland, while the increases range from $8 \mathrm{~mm}$ (in Gorzow grid-cell) to $104 \mathrm{~mm}$ (in Hel grid-cell). In general, the smallest increases are projected in the west (Wielkopolska region) while being the highest in the northern part of the country (Baltic See coast and Pomerania and Masuria Lake District). The only exception is the southeast of Poland (grid-cell Rzeszow), where a decrease of precipitation ( $28 \mathrm{~mm}$ in an average year) is projected (see Table 5). The general pattern of precipitation changes after five climate models is similar to the one described by MPI-M-REMO model. As for seasonal distribution, mostly increases are projected in the winter season and decreases in the summer. Summer increases of precipitation are projected for Baltic coast and the Masurian Lake District. The highest decreases of precipitation in summer are projected for the south of Poland (Figure 5).

On average, simulation of precipitation changes by five climate models is similar to the general pattern of changes described by MPI-M-REMO model. Increases of annual sums of precipitation around Poland are projected, with the higher increases in winter season and decreases in summer (except for areas in the northern part of Poland). The details of changes of the monthly and annual precipitation are included in Table 6 (annual values) and in Figure 6 (seasonal values).
5.2. Changes in Evaporation. The evaporation was calculated for eight land-use units, namely, coniferous and deciduous forests, arable lands (including cereal and root crops), meadows, wastelands, water bodies, and urban areas. MPI-MREMO model estimates that in average year the evaporation from water bodies (i.e., maximum potential evaporation) in Poland varies from $716 \mathrm{~mm}$ (in Suwalki grid-cell) to $837 \mathrm{~mm}$ (in Wlodawa grid-cell). The highest monthly values-about or above $140 \mathrm{~mm}$-are recorded in June and July.

Due to a large percentage of the cultivated area $(60.3 \%$ of the total area of Poland) and forested areas (30.7\%) [13] it seems interesting to describe the evaporation from agricultural lands (e.g., of cereal and root crops) as well as from forested areas in more detail. The evaporation for cereal crops (based on MPI-M-REMO model) in Poland differs annually from $508 \mathrm{~mm}$ (in Suwalki grid-cell) to $598 \mathrm{~mm}$ (in Wlodawa grid-cell). The highest monthly values, above $100 \mathrm{~mm}$, are recorded also in June and July. For the root crops these values are, respectively, from $498 \mathrm{~mm}$ (in gridcell Suwalki) to $593 \mathrm{~mm}$ (in Wlodawa and Hel grid-cells), while being above $105 \mathrm{~mm}$ in July. Coniferous forests occupy over 60 percent of the area of Polish forests. The MPI-MREMO model estimates the average annual evaporation from a coniferous forest in Poland from $652 \mathrm{~mm}$ (in Suwalki gridcell) to $768 \mathrm{~mm}$ (in Wlodawa grid-cell). The forest evaporates a lot of water during the growing season, with the highest amounts-more than $100 \mathrm{~mm}$ - each month from May to August (Table 7).

Projections for the future foresee mostly increases of the evaporation, among other due to increases of air temperature. The evaporation from water bodies (according to MPIM-REMO model) is projected to rise throughout Poland. The smallest changes (about $40 \mathrm{~mm}$ ) are projected for the Masurian Lake District, while being the highest for the southern part of Poland (with maximum value in Rzeszow grid-cell-71 mm). The increases on the arable ground will 


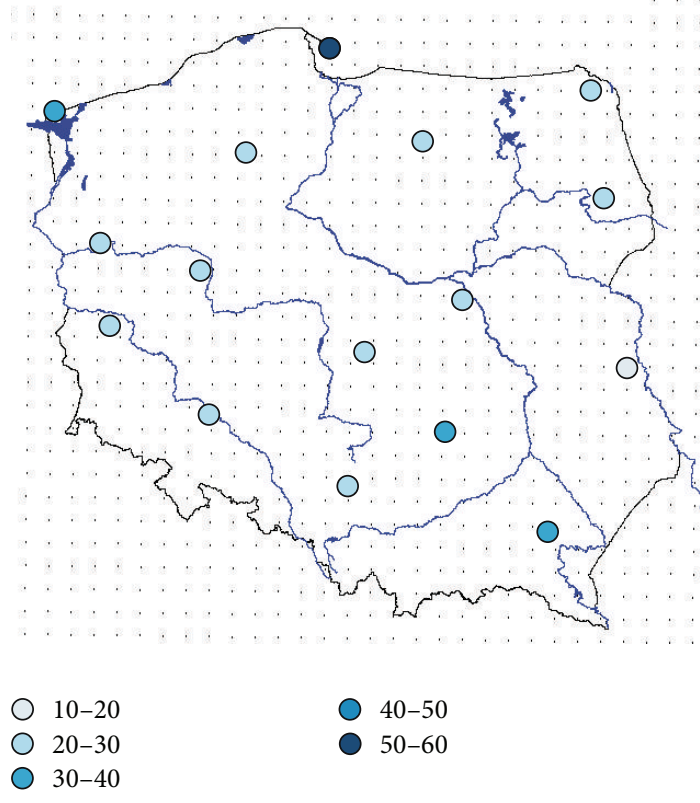

(a)

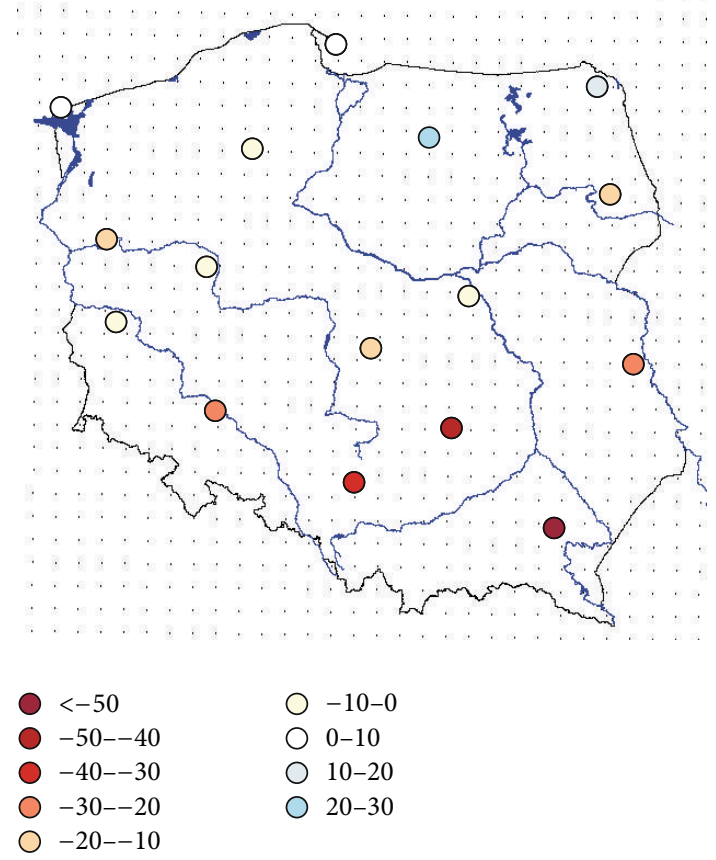

(b)

FIGURE 5: The changes of winter (a) and summer (b) precipitation [in mm] in the future (2061-2090) compared to the control period 19611990, based on the MPI-M-REMO model.

TABLE 6: The changes of the monthly and annual precipitation [in mm] in the future (2061-2090) compared to the control period 1961-1990average value from five models.

\begin{tabular}{|c|c|c|c|c|c|c|c|c|c|c|c|c|c|}
\hline Grid-cell & Jan & Feb & Mar & Apr & May & Jun & Jul & Aug & Sep & Oct & Nov & Dec & Year \\
\hline Bialystok & 17 & 13 & 10 & 10 & 15 & -8 & 6 & -6 & 3 & -4 & 9 & 16 & 81 \\
\hline Chojnice & 17 & 13 & 7 & 2 & 6 & 1 & 9 & -7 & 2 & 2 & 7 & 13 & 74 \\
\hline Gorzow & 16 & 9 & 7 & 6 & 10 & 1 & 0 & -11 & -1 & 3 & 10 & 14 & 61 \\
\hline Hel & 18 & 17 & 9 & 7 & 7 & 6 & 7 & -2 & 3 & 3 & 10 & 19 & 104 \\
\hline Katowice & 18 & 11 & 8 & 7 & 16 & -8 & -8 & -6 & 1 & -3 & 9 & 11 & 57 \\
\hline Kielce & 15 & 11 & 8 & 4 & 13 & -14 & -6 & -5 & 4 & -3 & 12 & 14 & 53 \\
\hline Lodz & 16 & 11 & 6 & 7 & 16 & -5 & 1 & -6 & 3 & -4 & 10 & 15 & 69 \\
\hline Olsztyn & 19 & 13 & 11 & 6 & 8 & 3 & 8 & -1 & -2 & -2 & 9 & 15 & 89 \\
\hline Poznan & 16 & 10 & 4 & 3 & 6 & -2 & 4 & -9 & 0 & -2 & 9 & 14 & 52 \\
\hline Rzeszow & 15 & 14 & 6 & 8 & 11 & -20 & -11 & -12 & 3 & -3 & 10 & 12 & 34 \\
\hline Suwalki & 19 & 15 & 13 & 8 & 9 & -3 & 4 & -4 & 1 & -1 & 8 & 15 & 83 \\
\hline Swinoujscie & 15 & 14 & 10 & 4 & 8 & 6 & 7 & -3 & 5 & 3 & 11 & 19 & 98 \\
\hline Warszawa & 15 & 11 & 7 & 8 & 14 & -5 & 4 & -2 & 2 & -5 & 12 & 15 & 76 \\
\hline Wlodawa & 14 & 12 & 7 & 6 & 13 & -17 & 1 & -11 & 5 & -3 & 10 & 16 & 53 \\
\hline Wroclaw & 14 & 11 & 5 & 5 & 17 & -2 & -6 & -7 & -2 & 0 & 8 & 15 & 57 \\
\hline Zielona G. & 15 & 10 & 2 & 5 & 13 & 0 & 3 & -3 & -1 & 3 & 10 & 12 & 69 \\
\hline
\end{tabular}

probably vary from about $30 \mathrm{~mm}$ in the Baltic Sea coast and the Masurian Lake District to more than $60 \mathrm{~mm}$ in the south of Poland. The increases of evaporation from forested areas will be even higher. They are projected at about $40 \mathrm{~mm}$ in Masurian Lake District to even $70 \mathrm{~mm}$ in the south of the country (see Figure 7(a) and Table 8). The MPI-M-REMO model projects the largest changes of evaporation at the end of the growing season (particularly in August).
Other models, similarly to the MPI-M-REMO model, project the same direction of changes of the evaporation values - that is, increases of evaporation from different landuse units (see Figure 7(b), Table 9). Differences, sometimes significant ones, concern these surpluses/values, as well as distribution within one year. Thus, relatively a great unanimity of 3 models (C4IRCA3, ETHZ, and KNMI) is prevailing as for the annual values. For these 3 models the increases 


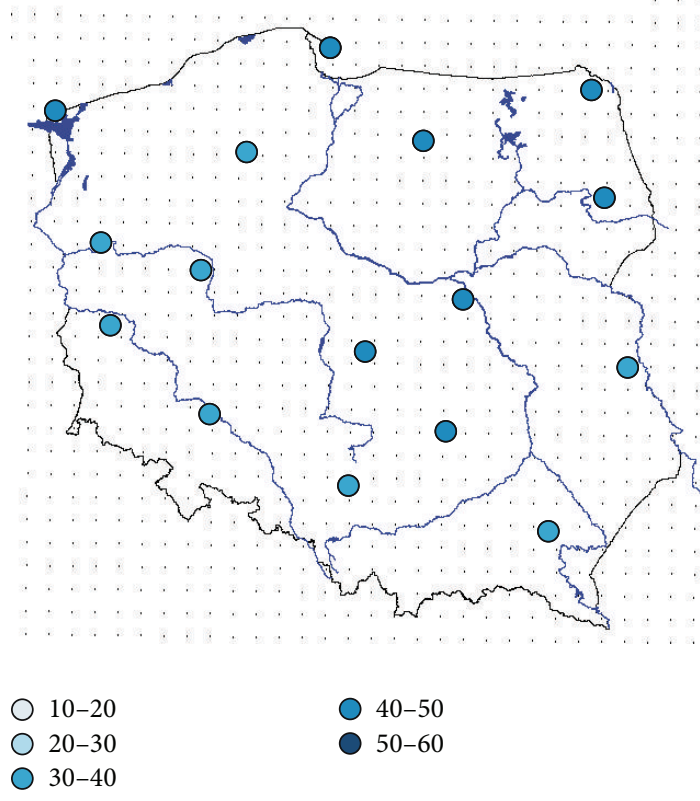

(a)

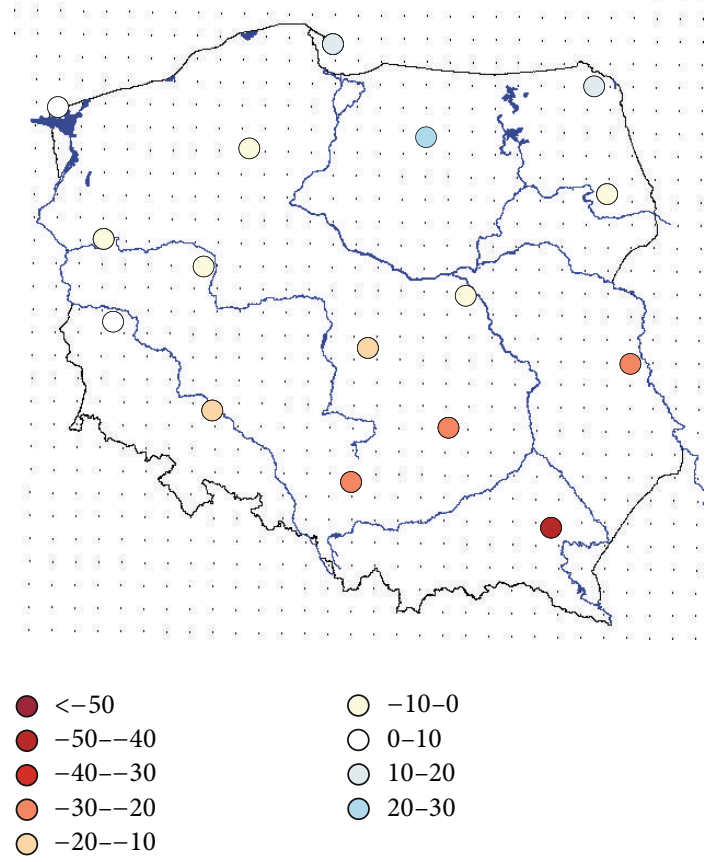

(b)

FIGURE 6: The changes of winter (a) and summer (b) precipitation [in mm] in the future (2061-2090) compared to the control period 19611990, based on five models.

TABLE 7: The annual values of evaporation [in mm] for different land-use units for the control period 1961-1990 compared to the control period 1961-1990, based on the MPI-M-REMO model.

\begin{tabular}{lcccccccc}
\hline Grid-cell & Deciduous forest & Coniferous forest & Urban areas & Water bodies & Wastelands & Meadows & Cereal crops & Root crops \\
\hline Bialystok & 596 & 654 & 307 & 718 & 381 & 466 & 510 & 500 \\
Chojnice & 617 & 678 & 321 & 744 & 393 & 485 & 528 & 517 \\
Gorzow & 644 & 706 & 340 & 772 & 411 & 508 & 552 \\
Hel & 678 & 736 & 400 & 803 & 477 & 552 & 588 & 541 \\
Katowice & 640 & 699 & 348 & 763 & 419 & 510 & 552 \\
Kielce & 649 & 711 & 344 & 778 & 418 & 513 & 557 \\
Lodz & 644 & 706 & 337 & 773 & 410 & 506 & 551 \\
Olsztyn & 609 & 667 & 321 & 731 & 394 & 480 & 522 \\
Poznan & 644 & 707 & 335 & 774 & 407 & 506 & 551 \\
Rzeszow & 663 & 725 & 355 & 790 & 426 & 524 & 568 \\
Suwalki & 594 & 652 & 307 & 716 & 382 & 465 & 547 \\
Swinoujscie & 663 & 721 & 372 & 788 & 448 & 529 & 568 \\
Warszawa & 641 & 702 & 334 & 768 & 406 & 502 & 543 \\
Wlodawa & 703 & 768 & 370 & 837 & 440 & 551 & 561 \\
Wroclaw & 654 & 715 & 355 & 779 & 425 & 520 & 598 \\
Zielona G. & 657 & 719 & 353 & 784 & 422 & 521 & 563
\end{tabular}

of evaporation from the free surface water in Poland in the future amount to about $30-40 \mathrm{~mm}$. For the METO-HC model, much differing from the other models, changes are twice higher, of $60-80 \mathrm{~mm}$. There is an agreement between these 4 models as regards when, in which months of the year, those changes will take place. C4IRCA3, ETHZ, KNMI, and METO-HC models similarly project the highest changes in summer months (June-July-August), but in case of the METO-HC model summer increases of evaporation are the third part of all annual increases while in C4IRCA3 and ETHZ models over half of the annual changes are projected in summer. The changes of the evaporation values from water 


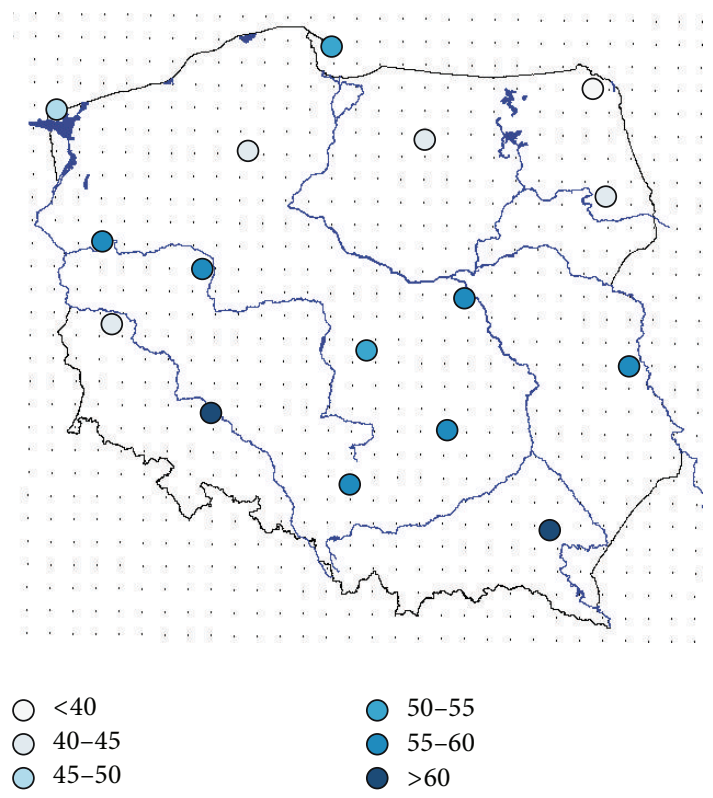

(a)

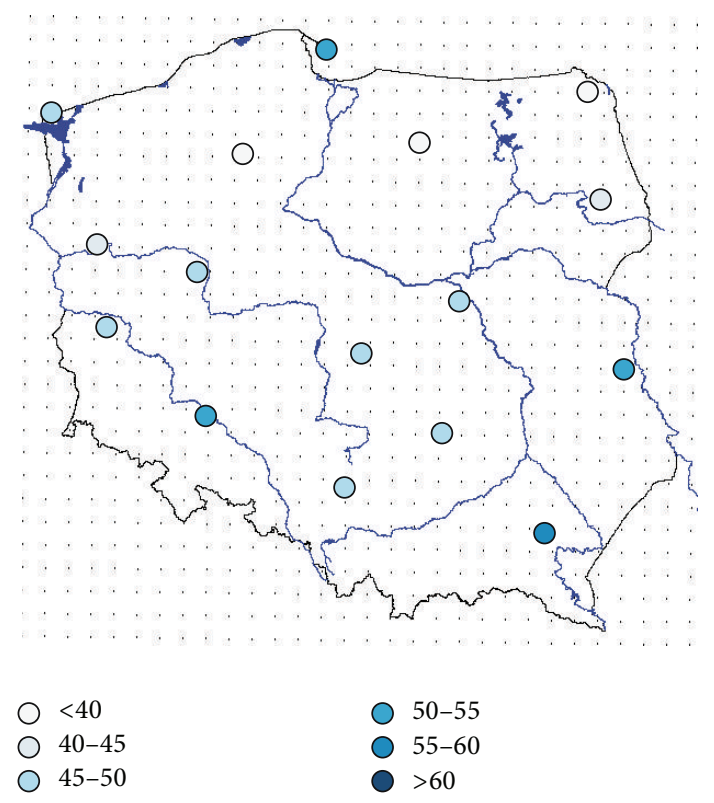

(b)

FIGURE 7: The increases of the annual evaporation from the water bodies [in mm] in the future (2061-2090) compared to the control period 1961-1990, based on MPI-M-REMO model (a) and average value from five models (b).

TABLE 8: The increases of the annual evaporation [in mm] for different land-use units in the future (2061-2090) compared to the control period 1961-1990, based on the MPI-M-REMO model.

\begin{tabular}{lcccccccc}
\hline Grid-cell & Deciduous forest & Coniferous forest & Urban areas & Water bodies & Wastelands & Meadows & Cereal crops & Root crops \\
\hline Bialystok & 37 & 40 & 19 & 42 & 13 & 29 & 29 & 31 \\
Chojnice & 40 & 42 & 21 & 44 & 17 & 31 & 31 & 34 \\
Gorzow & 52 & 54 & 33 & 55 & 29 & 42 & 43 \\
Hel & 47 & 50 & 24 & 52 & 17 & 37 & 39 & 38 \\
Katowice & 55 & 57 & 36 & 58 & 31 & 45 & 45 \\
Kielce & 55 & 57 & 35 & 59 & 30 & 44 & 45 \\
Lodz & 50 & 52 & 30 & 53 & 25 & 40 & 40 \\
Olsztyn & 39 & 41 & 20 & 43 & 15 & 30 & 31 \\
Poznan & 52 & 54 & 32 & 55 & 28 & 42 & 43 \\
Rzeszow & 68 & 70 & 46 & 71 & 41 & 56 & 57 \\
Suwalki & 32 & 35 & 13 & 37 & 8 & 24 & 24 \\
Swinoujscie & 42 & 45 & 22 & 46 & 16 & 32 & 34 \\
Warszawa & 52 & 55 & 32 & 56 & 28 & 42 & 43 \\
Wlodawa & 55 & 57 & 34 & 59 & 29 & 44 & 43 \\
Wroclaw & 63 & 42 & 43 & 66 & 39 & 52 & 45 \\
Zielona G. & 40 & 21 & 43 & 17 & 30 & 53 \\
\hline
\end{tabular}

bodies projected by five models for the future of 2061-2090 are presented in Table 10 for the example of the grid-cell of Poznan.

5.3. Changes in Runoff. For every grid-cell analysed in this paper (usually a square of $25 \mathrm{~km} \times 25 \mathrm{~km}$ ) a total evaporation from the grid-cell area (taking into consideration the share of individual land-use units) is estimated. The values of the total evaporation from the area as well as the values of precipitation (directly available from the model) were the basis for the runoff estimations. The values of a runoff coefficient from every grid-cell are used for detailed analyses.

The estimated values of the runoff coefficient based on modelled data are somewhat higher than the real ones. In principle, they are similar to the values typical for the observations from a wet year. This is probably caused first of all by the overestimation of precipitation and inaccuracies in the distribution of monthly sums of precipitation. Secondly, one should expect overestimated values of the runoff coefficient due to quite substantial percentage of urbanized areas in 
TABLE 9: The increases of the annual evaporation [in $\mathrm{mm}$ ] from different land-use units in the future (2061-2090) compared to the control period 1961-1990, based on five models (average values).

\begin{tabular}{|c|c|c|c|c|c|c|c|c|}
\hline Grid-cell & Deciduous forest & Coniferous forest & Urban areas & Water bodies & Wastelands & Meadows & Cereal crops & Root crops \\
\hline Bialystok & 36 & 39 & 11 & 41 & 5 & 24 & 25 & 29 \\
\hline Chojnice & 33 & 36 & 10 & 38 & 5 & 22 & 23 & 25 \\
\hline Gorzow & 41 & 43 & 16 & 45 & 11 & 28 & 29 & 34 \\
\hline Hel & 47 & 51 & 18 & 52 & 10 & 33 & 36 & 36 \\
\hline Katowice & 44 & 47 & 18 & 48 & 12 & 30 & 32 & 37 \\
\hline Kielce & 44 & 47 & 17 & 48 & 11 & 29 & 31 & 37 \\
\hline Lodz & 43 & 46 & 17 & 47 & 11 & 29 & 31 & 36 \\
\hline Olsztyn & 34 & 37 & 10 & 38 & 4 & 22 & 23 & 26 \\
\hline Poznan & 44 & 46 & 18 & 48 & 12 & 30 & 32 & 36 \\
\hline Rzeszow & 54 & 57 & 25 & 58 & 18 & 38 & 40 & 46 \\
\hline Suwalki & 32 & 35 & 8 & 37 & 1 & 21 & 21 & 24 \\
\hline Swinoujscie & 43 & 47 & 16 & 48 & 9 & 29 & 32 & 34 \\
\hline Warszawa & 45 & 47 & 18 & 49 & 12 & 31 & 32 & 37 \\
\hline Wlodawa & 48 & 51 & 20 & 53 & 13 & 33 & 34 & 40 \\
\hline Wroclaw & 49 & 52 & 24 & 53 & 19 & 35 & 37 & 43 \\
\hline Zielona G. & 42 & 45 & 18 & 46 & 12 & 29 & 30 & 35 \\
\hline
\end{tabular}

TABLE 10: The increases of the monthly evaporation from water bodies [in mm] in the future (2061-2090) compared to the control period 1961-1990, based on five models-example of the grid-cell of Poznan.

\begin{tabular}{lccccc}
\hline \multicolumn{5}{c}{} & \multicolumn{4}{c}{ Models } \\
& C4IRCA & ETHZ & KNMI & METO-HC & MPI-M-REMO \\
\hline Jan & 3.7 & 1.1 & 4.1 & 5.6 & 7.3 \\
Feb & 0.1 & 0.8 & 3.9 & 6.8 & 8.4 \\
Mar & -0.8 & 1.4 & 2.7 & 9.3 & 7.5 \\
Apr & 1.0 & -0.2 & 1.0 & 0.3 & 0.6 \\
May & 2.7 & 2.1 & 2.6 & 3.8 & 2.0 \\
Jun & 4.8 & 4.4 & 4.7 & 6.8 & 3.7 \\
Jul & 7.4 & 6.1 & 4.9 & 9.2 & 4.0 \\
Aug & 7.4 & 8.7 & 4.5 & 12.1 & 4.6 \\
Sep & 5.0 & 3.6 & 3.1 & 5.0 & 3.4 \\
Oct & 2.7 & 2.4 & 2.3 & 2.7 & 2.4 \\
Nov & 0.3 & 2.6 & 2.2 & 9.1 & 6.8 \\
Dec & 3.6 & 0.4 & 0.5 & 5.5 & 4.5 \\
\hline Year & 37.7 & 33.5 & 36.6 & 76.2 & 55.3 \\
\hline
\end{tabular}

selected grid-cells (with the maximum value for Warszawa grid-cell about $0.52 \%$ of the area). The runoff coefficients based on the five RCMs for the control period and for the future are presented in Table 11. The spatial variability of the runoff coefficient for Poland in the control period 1961-1990 is presented in Figure 8. Figure 8 presents two variants of the runoff coefficient values: first one based on MPI-M-REMO model and the second one as an average value from five models.

According to RCMs, in an average year at present no area in Poland experiences a dramatic problem with water scarcity or surpluses, though some water scarcity appears during summer. Furthermore, regional climate models foresee slight changes of the annual runoff coefficient in a normal year (if the land-use changes in the future are not taken into consideration). In Figure 9 estimated values of the runoff coefficient in the future 2061-2090 are presented. Figure 9, presented similarly to the convention applied to Figure 8, illustrates two variants of the foreseen changes: (a) based on MPI-M-REMO model and (b) as an average value from five models.

Two models-METO-HC and MPI-M-REMO-point at slight decreasing, while three-C4IRCA3, ETHZ, and KNMI-point at slight increasing of the runoff coefficient around Poland. In different models, the most severe scarcity of water could appear during several seasons, for example, summer and autumn, ETHZ, autumn and winter, C4IRCA3, or summer and winter, KNMI, and so forth.

These differences result from different preconditions and different projections of changes in some meteorological variables, most notably precipitation. In any case, while all the models are compatible with respect to the mean temperature increase, not all of them are compatible as to the changes in precipitation. All the studied ENSEMBLES RCMs indicate an increase in winter precipitation (with different magnitudes), but models disagree on projections for the summer precipitation. Thus, for example, ETHZ model foresees small decreases in precipitation from June to October (on the level of 10$20 \%$ ), while C4IRCA3 projects large increases in precipitation from May to July and in May alone even 50\% higher.

\section{Conclusions}

In the present climate, many regions of Poland (and predominantly the Wielkopolska region) suffer frequent shortages of water, especially in the growing season. On the other hand, increase in intense precipitation is observed. In the last decades Poland experienced many extreme events connected with heavy precipitations, for example, floods in 1997 and 
TABLE 11: The annual runoff coefficient for the control period 1961-1990 and for the future 2061-2090 based on five models.

\begin{tabular}{|c|c|c|c|c|c|c|c|c|c|c|}
\hline \multirow[b]{2}{*}{ C4IRCA } & \multicolumn{4}{|c|}{ Control period (1961-1990) } & & \multicolumn{5}{|c|}{ Future (2061-2090) } \\
\hline & ETHZ & KNMI & METO & MPI & & C4IRCA & ETKZ & KNMI & METO & MPI \\
\hline 0.24 & 0.25 & 0.24 & 0.24 & 0.32 & Bialystok & 0.33 & 0.31 & 0.33 & 0.24 & 0.33 \\
\hline 0.25 & 0.19 & 0.30 & 0.27 & 0.18 & Chojnice & 0.35 & 0.23 & 0.33 & 0.26 & 0.20 \\
\hline 0.15 & 0.14 & 0.23 & 0.19 & 0.23 & Gorzow & 0.28 & 0.18 & 0.24 & 0.16 & 0.18 \\
\hline-0.13 & -0.05 & 0.00 & -0.12 & -0.01 & Hel & 0.01 & 0.05 & 0.05 & -0.09 & 0.06 \\
\hline 0.26 & 0.30 & 0.34 & 0.42 & 0.26 & Katowice & 0.33 & 0.31 & 0.37 & 0.38 & 0.22 \\
\hline 0.25 & 0.25 & 0.30 & 0.33 & 0.16 & Kielce & 0.30 & 0.24 & 0.32 & 0.28 & 0.11 \\
\hline 0.28 & 0.23 & 0.27 & 0.41 & 0.20 & Lodz & 0.34 & 0.30 & 0.29 & 0.38 & 0.18 \\
\hline 0.27 & 0.19 & 0.33 & 0.21 & 0.27 & Olsztyn & 0.36 & 0.27 & 0.36 & 0.21 & 0.29 \\
\hline 0.16 & 0.24 & 0.20 & 0.26 & 0.21 & Poznan & 0.26 & 0.23 & 0.23 & 0.22 & 0.17 \\
\hline 0.11 & 0.27 & 0.23 & 0.49 & 0.30 & Rzeszow & 0.18 & 0.29 & 0.23 & 0.44 & 0.21 \\
\hline 0.37 & 0.19 & 0.36 & 0.27 & 0.23 & Suwalki & 0.44 & 0.26 & 0.39 & 0.26 & 0.27 \\
\hline 0.06 & 0.14 & 0.15 & 0.01 & 0.22 & Swinoujscie & 0.16 & 0.21 & 0.18 & 0.07 & 0.25 \\
\hline 0.23 & 0.34 & 0.33 & 0.33 & 0.41 & Warszawa & 0.36 & 0.40 & 0.35 & 0.30 & 0.39 \\
\hline 0.05 & 0.11 & 0.12 & 0.12 & 0.13 & Wlodawa & 0.14 & 0.15 & 0.11 & 0.07 & 0.09 \\
\hline 0.11 & 0.34 & 0.21 & 0.40 & 0.19 & Wroclaw & 0.21 & 0.35 & 0.25 & 0.35 & 0.15 \\
\hline 0.09 & 0.16 & 0.12 & 0.27 & 0.13 & Zielona G. & 0.20 & 0.18 & 0.20 & 0.22 & 0.11 \\
\hline 0.17 & 0.21 & 0.23 & 0.26 & 0.21 & Average & 0.27 & 0.25 & 0.26 & 0.24 & 0.20 \\
\hline
\end{tabular}
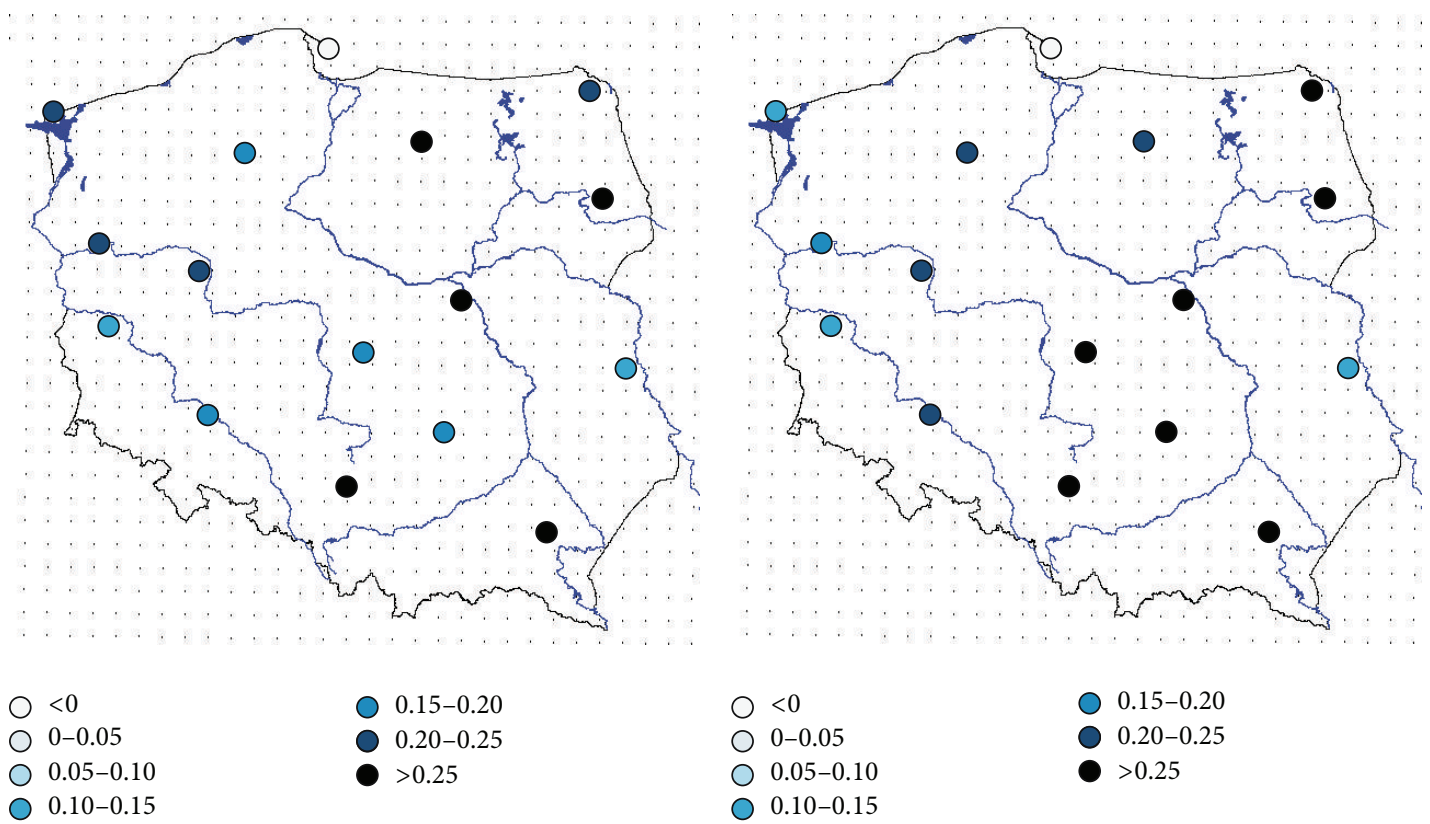

$\begin{array}{ll}\bigcirc & <0 \\ \bigcirc & 0-0.05 \\ \bigcirc & 0.05-0.10 \\ \bigcirc & 0.10-0.15\end{array}$

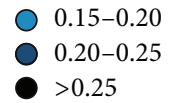

(a)

(b)

FIGURE 8: The annual runoff coefficient for the control period 1961-1990: (a) based on MPI-M-REMO model and (b) an average value from five models.

2010. Climate changes noticeable today are projected to intensify in the future. Therefore, water shortages/surpluses may be even more common and more severe in the future. There is still a great deal of uncertainty regarding likely climate change impacts on water resources. However, there is no doubt that changes in thermal characteristics as well as in precipitation will influence changes in the water balance of the country.

Due to insufficient consistency between climate models a possible range of changes should be presented; hence the multimodel projections from ENSEMBLES Project of the European Union are used in this study. According to 


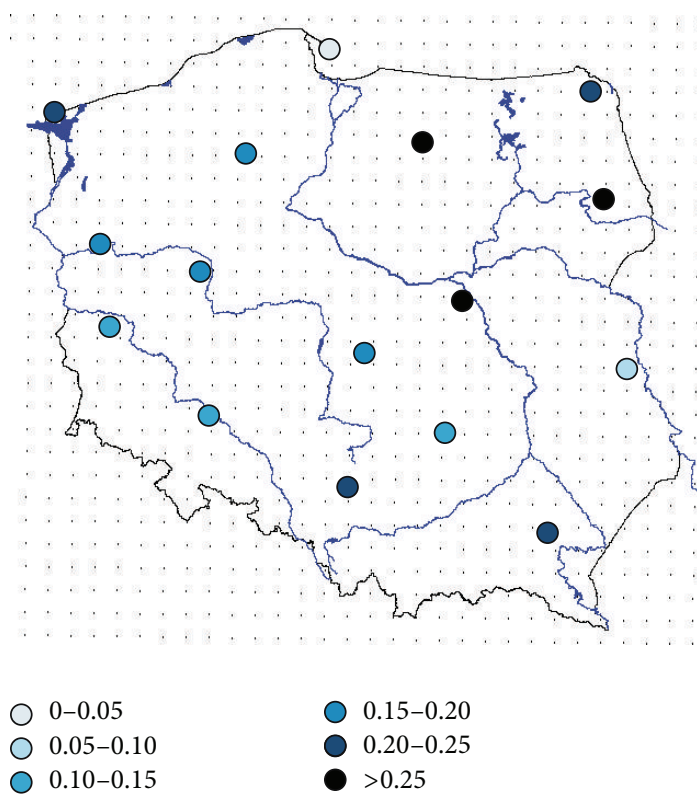

(a)

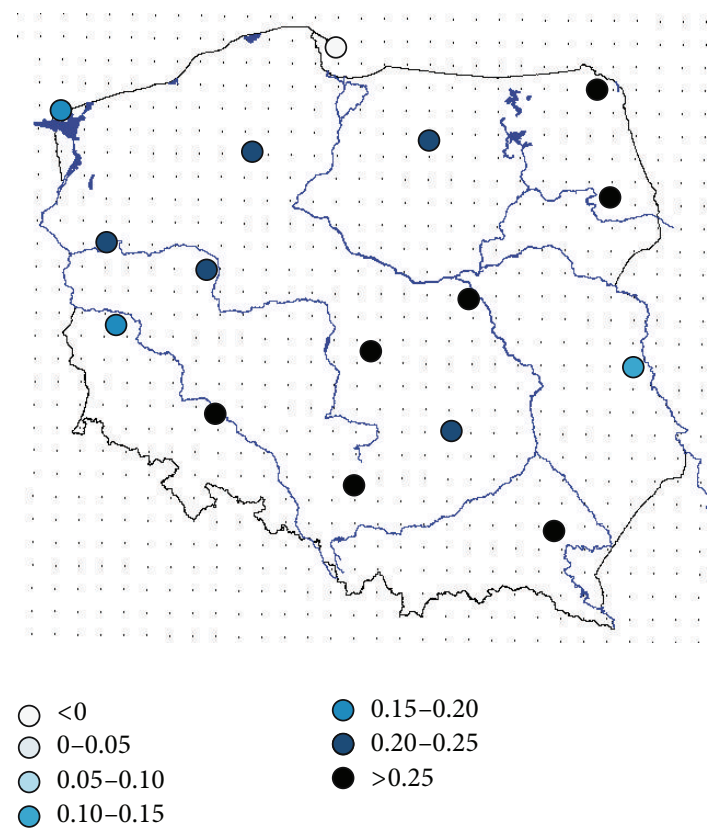

(b)

Figure 9: The annual runoff coefficient for the future 2061-2090: (a) based on MPI-M-REMO model and (b) an average value from five models.

applied RCMs, at present in an average year no area in Poland experiences a dramatic problem with water scarcity or surplus, though some water scarcity appears during summer.

Climate models project changes in the water availability in Poland in the future caused mainly by a rise of temperature, as well as changes of values and distribution of precipitation. The average value from five climate models points at increases of annual sums of precipitation around Poland, with the higher increases in winter season and decreases in summer. Simultaneously, increases of evaporation from different landuse units are projected. As a result, regional climate models foresee slight changes of the annual runoff coefficient in a normal year (if the land-use changes in the future are not taken into consideration). However, there is a strong uncertainty in future projections. Two models, METO-HC and MPI-M-REMO, point at slight worsening, while three, C4IRCA3, ETHZ, and KNMI, point at slight improvement of the water conditions in Poland.

To conclude, projections for the future indicate continuing water problems in Poland. Even though projected changes in water balance are not strong enough to force changes in the land-use structure, the values of the water balance components at present and in the future support the necessity to modify the landscape in such a way as to improve the water balance in many regions of Poland. In any case, essential system solutions capturing water outflow from the area of Poland in early spring and optimal water management in the agriculture could be put into practice. Probably, so-called small water retention will need to be increased and/or building of water reservoirs will be required. Better adaptation of the kind of cultivation plants/species to climatic conditions and to the accessible water quality could also be necessary.

\section{Conflict of Interests}

The author declares that there is no conflict of interests regarding the publication of this paper.

\section{Acknowledgment}

Support of the Research Project CHASE-PL (Climate Change Impact Assessment for Selected Sectors in Poland) of the Polish-Norwegian Research Programme is gratefully acknowledged.

\section{References}

[1] IPCC, Climate Change 2013: The Physical Science Basis. Contribution of Working Group I to the Fifth Assessment Report of the Intergovernmental Panel on Climate Change, Cambridge University Press, Cambridge, UK, 2013, edited by: T. F. Stocker, D. Qin, G.-K. Plattner, M. Tignor, S. K. Allen, J. Boschung, A. Nauels, Y. Xia, V. Bex, P. M. Midgley.

[2] T. G. Huntington, "Evidence for intensification of the global water cycle: review and synthesis," Journal of Hydrology, vol. 319, no. 1-4, pp. 83-95, 2006.

[3] R. T. Wetherald and S. Manabe, "Simulation of hydrologic changes associated with global warming," Journal of Geophysical Research, vol. 107, no. D19, pp. ACL 7-1-ACL 7-15, 2002.

[4] Z. W. Kundzewicz, L. J. Mata, N. W. Arnell et al., "The implications of projected climate change for freshwater resources and their management," Hydrological Sciences Journal, vol. 53, no. 1, pp. 3-10, 2008.

[5] S. I. Seneviratne, N. Nicholls, D. Easterling et al., "Changes in climate extremes and their impacts on the natural physical environment," in Managing the Risks of Extreme Events and 
Disasters to Advance Climate Change Adaptation, C. B. Field, V. Barros, T. F. Stocker et al., Eds., A Special Report of Working Groups I and II of the Intergovernmental Panel on Climate Change (IPCC), pp. 109-230, Cambridge University Press, Cambridge, UK, 2012.

[6] IPCC SRES, N. Nakićenović, and R. Swart, Eds., Special Report on Emissions Scenarios: A Special Report of Working Group III of the Intergovernmental Panel on Climate Change, Cambridge University Press, 2000.

[7] M. Szwed, G. Karg, I. Pińskwar et al., "Applying agricultural, hydrological, and human health indices to evaluate the changing risk of weather extremes in Poland, based on multi-model ensemble climate projections," Natural Hazards and Earth System Sciences, vol. 10, pp. 1725-1737, 2010.

[8] K. E. Taylor, "Summarizing multiple aspects of model performance in a single diagram," PCMDI Report 65, Program for Climate Model Diagnosis and Intercomparison, Lawrence Livermore National Laboratory, University of California, Livermore, Calif, USA, 2000.

[9] J. Olejnik and A. Kędziora, "A model for heat and water balance estimation and its application to land use and climate variation," Earth Surface Processes and Landforms, vol. 16, no. 7, pp. 601-617, 1991.

[10] A. Kędziora, Podstawy Agroklimatologii, PWRiL, Warsaw, Poland, 1999.

[11] T. Górski and K. Górska, "An algorithm for evaluating the cycle of sunshine duration in Poland," in Book of Proceedings: EuroSun 98, The Second ISES Europe Solar Congress : [Portorož, Slovenia, September 14-17, 1998], vol. 1, pp. 1-6, 1998.

[12] J. Leśny, Bilans cieplny powierzchni czynnej wybranych upraw $w$ Wielkopolsce, vol. 429 of Rozprawy Naukowe, Wydawnictwo Uniwersytetu Przyrodniczego, 2011.

[13] Statistical Yearbook of Agriculture, GUS, 2013, http://stat.gov .pl/cps/rde/xbcr/gus/rs_rocznik_rolnic-twa_2012.pdf. 

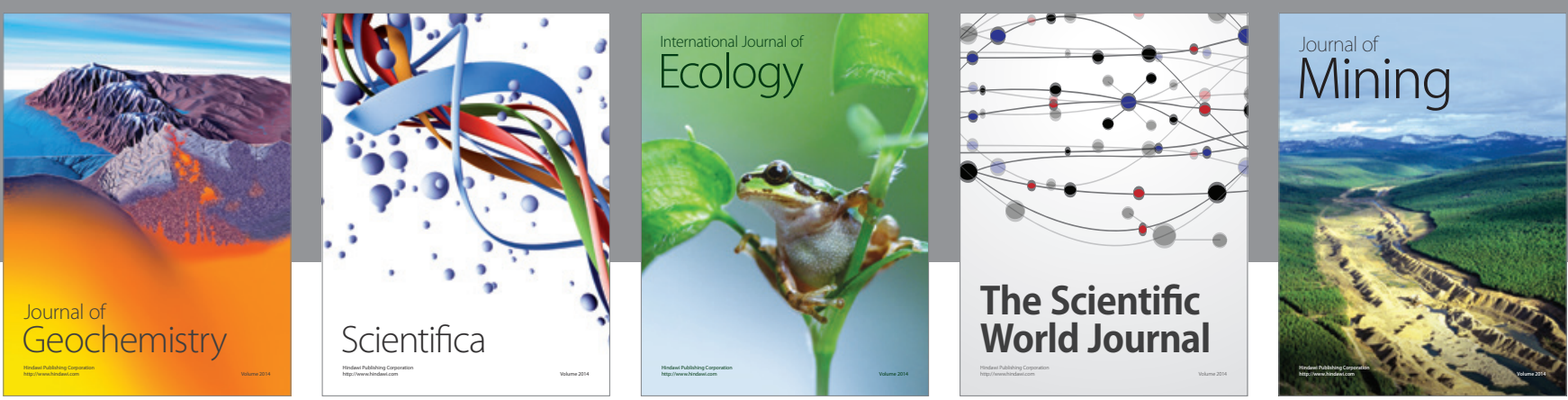

The Scientific World Journal
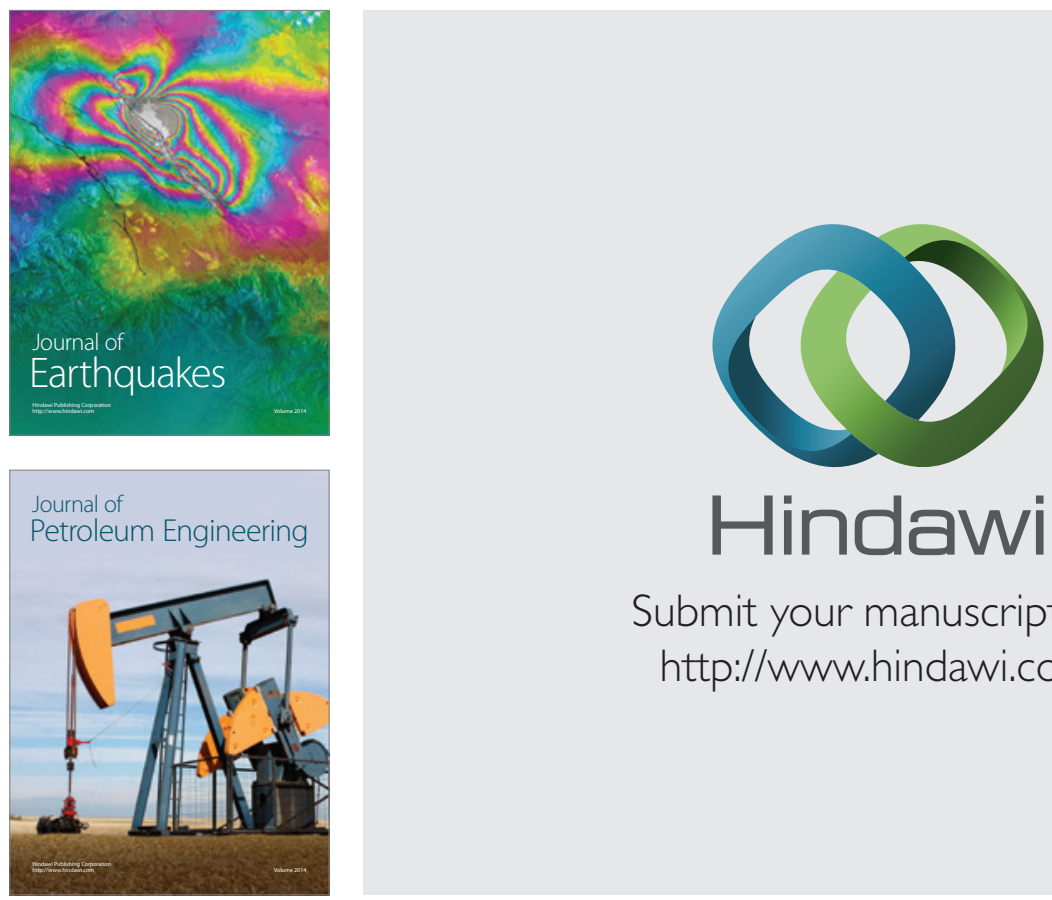

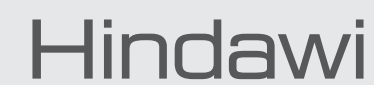

Submit your manuscripts at

http://www.hindawi.com
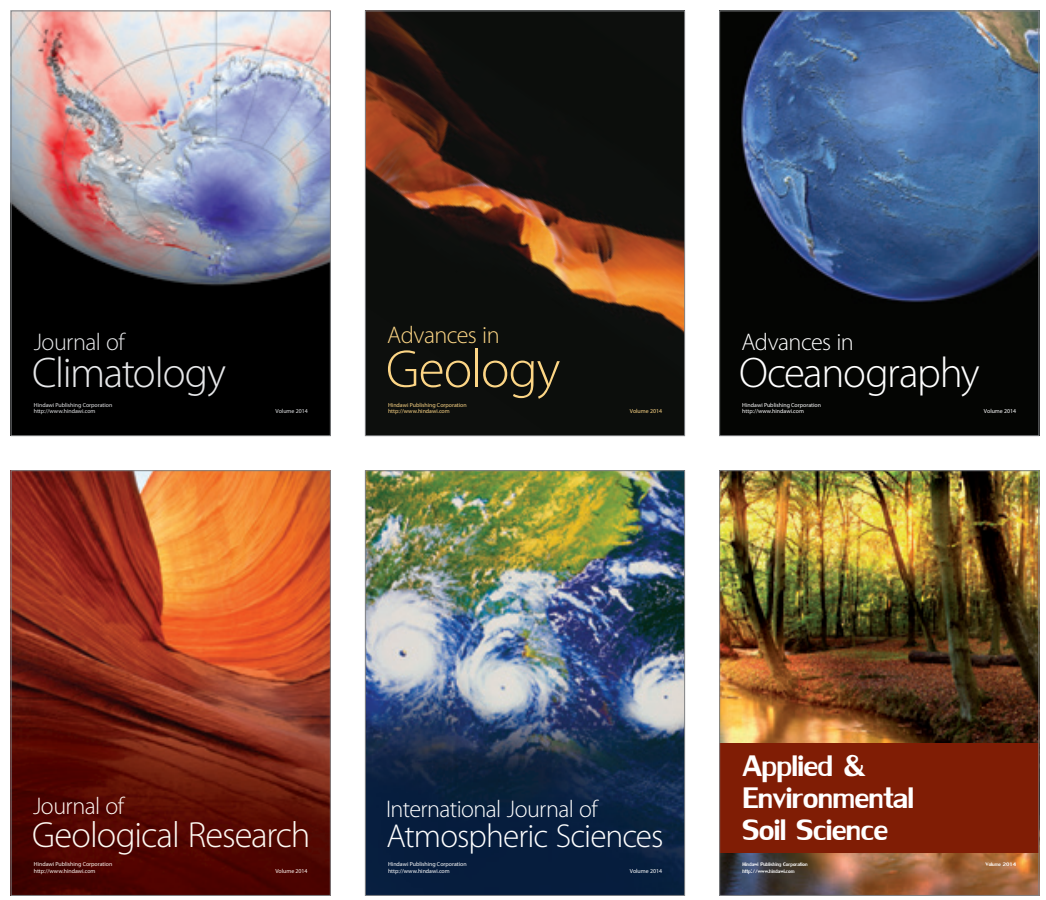
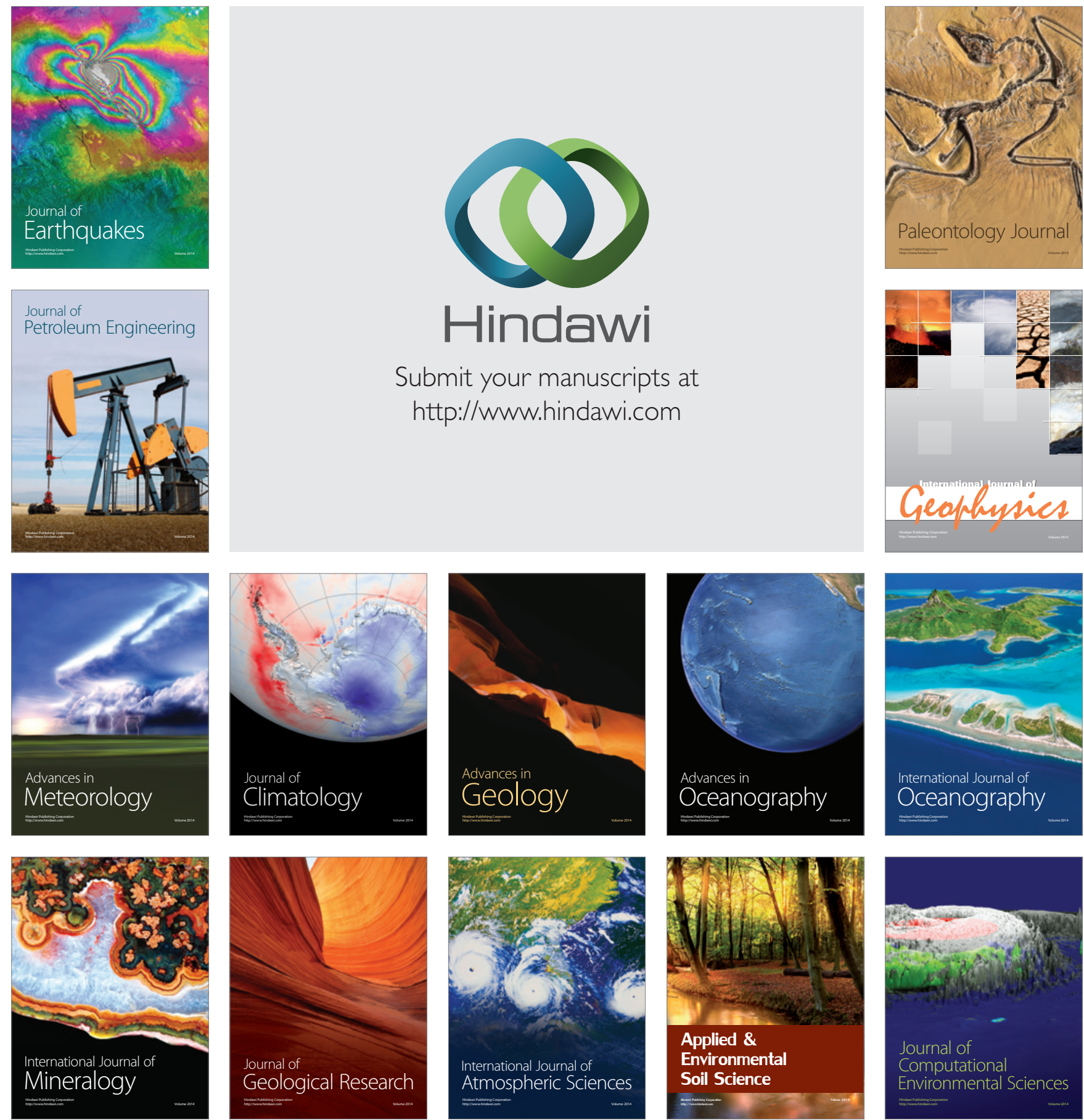